\title{
EFFECT OF DIETARY CALCIUM LEVEL ON THE PRODUCTIVE PERFORMANCE OF NAKED NECK (SHARKASI) LAYING HENS
}

\author{
M.N. Makled and A. Abd El-Rahman
}

Department of Animal and Poultry Production, University of Assiut, Assiut, Egypt

\section{SUMMARY}

A total number of 428 laying hens from three genotypes, heterozygous naked neck (Na/na), homozygous naked neck ( $\mathrm{Na} / \mathrm{Na}$ ) and normally feathered (na/na) was used to study the combining effect of Na gene and dietary calcium level (3.47\%, 2.51\%) on egg production and egg shell quality till 54 wks of age. The results were as follows:

1- The presence of $\mathrm{Na}$ gene or high calcium level $(3.45 \%)$ reduced significantly $(P<0.01)$ the age of sexual maturity.

2- The Na gene improved egg number and average laying rate by $11.7 \%$ and $10.1 \%$ respectively, whereas egg mass increased by $18.9 \%$ and $15.5 \%$ for the Na/na and $\mathrm{Na} / \mathrm{Na}$ genotypes, respectively. High calcium level (3.47\%) significantly $(P<0.01)$ improved average laying rate and total egg number by $3.5 \%$, whereas it increased the total egg mass by $6 \%$ when compared with low dietary calcium level $(2.51 \%)$. A significant interaction $(P<0.01)$ was found between Na gene and dietary calcium level where the improvement in egg production due to high calcium level (3.47\%) was more pronounced for the Na/- birds than the normal feathering (na/na) counterparts.

3- The presence of $\mathrm{Na}$ gene significantly $(P<0.01)$ increased egg weight and albumen percentage, whereas it reduced yolk and shell quality. High calcium level had no effect on albumen and yolk percentages, whereas it improved significantly egg shell percentage and shell thickness but without any effect on its breaking strength.

4- The naked neck birds (Na/-) exhibited a significant reduction $(P<0.01)$ in abdominal fat with an improvement of dressing by about 5.3\%. Also, an increase in ovary and oviduct percentage due to Na gene was observed with a significant reduction $(P<0.05)$ of serum calcium level. Dietary calcium level did not affect anatomical parameters and dressing percentages. High calcium level significantly increased oviduct and serum calcium percentages.

It can be concluded, that the $\mathrm{Na}$ - exhibited remarkable superiority in productive performance. Also, high dietary calcium (3.47\%) was more effective than low level $(2.51 \%)$ to enhance the performance of the Na/- genotypes as compared with normal (na/na) counterparts.

Keywords: Sharkasi layers, naked neck gene, calcium level, egg production

\section{INTRODUCTION}

In Upper Egypt, the naked neck gene $(\mathrm{Na})$ is widespread in unselected local chickens and known by farmers at various areas as Sharkasi chicken (Abd El-

Issued by The Egyptian Society of Animal Production 
Rahman, 1998). This gene reduces feather by $20-40 \%$ and is associated with an advantage in egg production performance under moderate conditions which was more pronounced under tropical and subtropical conditions (Abd El-Rahman, 1990, 2000a,b; Abd El-Rahman and El-Hammady, 2000; Horst et al., 1996; Singh et al., 2001 and Abd El-Rahman and Makled, 2006). The findings of Horst and Mathur (1994), Horst et al. (1996) and Abd El-Rahman (1990, 2000a,b) indicated that the advantage of $\mathrm{Na}$ gene involved with the persistency not only in medium or heavy body weight but also in lighter ones.

Slight disadvantage of naked neck birds $(\mathrm{Na} /-)$ was noticed for egg shell quality as measured by percentages of shell-less eggs and craked eggs, breaking strength and shell thickness (Merat, 1990; Abd El-Rahman, 2000a\&b, 2003 and Singh et al. 2001). However, Galal and Fathi (2002), El-Safty et al. (2003) and Mahrous et al. (2003) reported that $\mathrm{Na}$ gene increased shell weight and percentage compared to na allele.

Many investigators have established that calcium level is an essential nutrient for laying hens (Clunies et al., 1992; Bar et al., 2002 and Chowhdury and Smith, 2002). Inadequate calcium intake causes a remarkable demineralization of bone, low serum calcium and subsequently reduction in shell weight which followed by a decrease in egg production (Gilbert et al., 1981 and Roland et al., 1996). Excess of dietary calcium may cause reduction in egg production performance (Keshavarz, 1986 and El-Gendi et al., 1999). The NRC (1994) reported Ca requirements of $3.25 \%$ for hens consuming $100 \mathrm{~g}$ /day. It was reported that dietary calcium levels between $2.2 \%$ and $3.5 \%$ were necessary to maintain optimum production and shell quality (Hurwitz and Griminger, 1960 and Admosun and Kalango, 1973).

On the other hand, Cheng and Coon (1990), Abdallah et al. (1993); Bar et al. (2002) and Sohail and Roland (2002) showed that calcium level had no significant effect on egg production and weight. Abou-Egla (1995) reported that no significant differences due to calcium levels $(3 \%, 3.5 \%$ and $4 \%)$ on egg production whereas $4 \%$ calcium level increased significantly egg shell quality. Despite the differences between breeds and strains in egg shell quality, the calcium level had a highly significant effect on egg shell quality (Cluines et al., 1992; Abou Egla, 1995; Roland et al., 1996; Gordon and Roland, 1998 and Abd El-Rahman, 2003).

The aim of the present study was to evaluate the impact of different dietary calcium levels on egg production and shell quality of the naked neck (Sharkasi) laying hens.

\section{MATERIALS AND METHODS}

\section{Birds and experimental diets}

This study was carried out at Poultry Research Farm of Assiut University. From a basic stock, local brown heterozygous naked neck $(\mathrm{Na} / \mathrm{na})$ males and females mated to produce the offspring which were classified into the three genotypes to be used in this study namely: Heterozygous naked neck ( $\mathrm{Na} / \mathrm{na})$, homozygous naked neck $(\mathrm{Na} / \mathrm{Na})$ and normal feathering genotype (na/na).

At 18 wks of age, pullets from each genotype were leg banded, randomly divided in pens into two equal subgroups one of them fed diet with high calcium level $(3.47 \%)$ and the other received diet with low calcium level $(2.51 \%)$ as shown in Table (1).All birds were raised in floor pens under prevailing environmental 
conditions (Table 2). Birds received 14 lighting hours, and feed and water were available ad libitum throughout the whole experimental period (18-54 wks of age).

Table 1. Composition and analysis of the experimental diets

\begin{tabular}{|c|c|c|c|c|c|}
\hline \multicolumn{3}{|c|}{ Ingredients (\%) } & High calcium & & cium \\
\hline \multicolumn{3}{|c|}{ Ground yellow corn } & 62.60 & & \\
\hline \multicolumn{3}{|c|}{ Soybean meal } & 17.00 & & \\
\hline \multicolumn{3}{|l|}{ Gluten } & 5.00 & & \\
\hline \multicolumn{3}{|c|}{ Wheat bran } & 5.00 & & \\
\hline \multicolumn{3}{|c|}{ Vitamin mixture (1) } & 0.25 & & \\
\hline \multicolumn{3}{|c|}{ Mineral mixture (2) } & 0.10 & & \\
\hline \multicolumn{3}{|c|}{ Salt } & 0.25 & & \\
\hline \multicolumn{3}{|l|}{ Lysine } & 0.20 & & \\
\hline \multicolumn{3}{|l|}{ Methionine } & 0.10 & & \\
\hline \multicolumn{3}{|l|}{ Limestone } & 7.50 & & \\
\hline \multicolumn{3}{|l|}{ Bone meal } & 2.00 & & \\
\hline \multicolumn{6}{|c|}{ Calculated analysis: } \\
\hline \multicolumn{3}{|c|}{ Crude protein, $\%$} & 16.97 & & \\
\hline \multicolumn{3}{|c|}{ ME (Kcal/kg) } & 2850 & & \\
\hline \multicolumn{3}{|c|}{ Calcium, $\%$} & 3.47 & & \\
\hline \multicolumn{3}{|c|}{ Available phosphorus \% } & 0.37 & & \\
\hline \multicolumn{3}{|c|}{ Total phosphorus \% } & 0.61 & & \\
\hline \multicolumn{3}{|c|}{ Salt, $\%$} & 0.33 & & \\
\hline \multicolumn{3}{|c|}{ Crude fiber, $\%$} & 3.32 & & \\
\hline \multicolumn{3}{|l|}{ Lysine, \% } & 0.94 & & \\
\hline \multicolumn{3}{|c|}{ Methionine, $\%$} & 0.42 & & \\
\hline \multicolumn{3}{|c|}{ Methionine + Cystine, \% } & 0.69 & & \\
\hline \multicolumn{6}{|c|}{$\begin{array}{l}\text { 1- Vit. mix. Supplied the following per kilogram of the diet; Vit. A, } 5000 \mathrm{IU} \text {; Vit. } \\
\mathrm{D}_{3}, 1200 \mathrm{IU} ; \mathrm{B}_{2}, 4 \mathrm{mg} \text {; Vit. E, } 2 \mathrm{mg} \text {; Pantothenic, } 15 \mathrm{mg} \text {; Niacin, } 20 \mathrm{mg} \text {; Vit. } \mathrm{B}_{12}, 4 \\
\mathrm{mg} \text {; and Choline, } 1500 \mathrm{mg} \text {. } \\
\text { 2- Min. Mix. Supplied the follwing in milligram per kilogram of the diet; Mn, } 60 \text {; } \\
\mathrm{Zn}, 50 ; \mathrm{Fe}, 30 ; \mathrm{Cu}, 5 ; \mathrm{I}, 1.05 \text {, and Se, } 0.1 \text {. }\end{array}$} \\
\hline \multicolumn{6}{|c|}{$\begin{array}{l}\text { Table 2. Minimum and maximum degrees of ambient temperature }\left({ }^{\circ} \mathrm{C}\right) \text { and } \\
\text { relative humidity }(\%) \text { during the experimental period }(18-54 \mathrm{wks}) \text {. }\end{array}$} \\
\hline \multirow{2}{*}{$\begin{array}{l}\text { Laying } \\
\text { period }\end{array}$} & \multirow{2}{*}{$\begin{array}{l}\text { Age } \\
(\mathbf{w k s})\end{array}$} & \multicolumn{2}{|c|}{ Ambient temp. $\left({ }^{\circ} \mathrm{C}\right)$} & Relative & ity $(\%)$ \\
\hline & & Min. & Max. & Min. & Max. \\
\hline- & $18-22$ & 14 & 30 & 20 & 57 \\
\hline 1 & $23-26$ & 16 & 32 & 25 & 55 \\
\hline 2 & $27-30$ & 18 & 30 & 25 & 58 \\
\hline 3 & $31-34$ & 20 & 33 & 30 & 65 \\
\hline 4 & $35-38$ & 13 & 31 & 30 & 63 \\
\hline 5 & $39-42$ & 16 & 30 & 25 & 68 \\
\hline 6 & $43-46$ & 14 & 25 & 30 & 70 \\
\hline 7 & $47-50$ & 13 & 23 & 30 & 73 \\
\hline 8 & $51-54$ & 14 & 21 & 35 & 75 \\
\hline Average & & 15.80 & 28.30 & 27.80 & 64.90 \\
\hline
\end{tabular}




\section{Traits studied}

The following parameters were recorded and calculated: body weight $(\mathrm{BW})$ at 24 , 40 and $52 \mathrm{wk}$ of age, age of sexual maturity (ASM), laying rate (LR,\%) throughout 8 successive laying periods (28 days each), total egg number (TEN), average egg weight (AEW), average laying rate (ALR,\%) egg number and laying rate till 90 days from age at sexual maturity (E90 and LR90,\%) and total egg mass (TEM) .

At 40 and 52 wk of age, a random sample of 240 eggs from all genotypes were taken to determine egg quality parameters: egg weight, proportions and percentages of albumen, yolk and shell. Shell quality was measured as shell thickness and strength using a cracking machine (Germany - Wazau). At the same ages also, a random sample of 120 females from the different genotypes were slaughtered, defeathered and eviserated, then carcass, giblets, abdominal fat and reproductive organs were removed and weighed (Gilbert et al., 1983). Serum calcium and phosphorus were determined using commercial diagnostic kits.

\section{Statistical analysis}

Data of body weight, age at sexual maturity and different parameters of egg production from 428 laying hens (154, 132 and 142 hens of $\mathrm{Na} / \mathrm{na}, \mathrm{Na} / \mathrm{Na}$ and na/na genotypes, respectively) were subjected to analysis of variance using General Linear Models (GLM) procedure of SAS (SAS, Institute 1990) by the following model:

$Y_{i j k}=\mu+G_{i}+T_{j}+(G x T)_{i j}+E_{i j k}$

where $Y_{i j k}$ is the $k^{\text {th }}$ observation of the $i^{\text {th }}$ genotype and $j^{\text {th }}$ calcium level, $\mu$ is the overall mean, $G_{i}$ is the effect of $i^{\text {th }}$ genotype, $T_{j}$ is the effect of $j^{\text {th }}$ calcium level; $(\mathrm{GxT})_{\mathrm{ij}}$ is the interaction effect of genotype with calcium level and $\mathrm{E}_{\mathrm{ijk}}$ is the random error.

Results of egg quality and physiological parameters were analysed according to the following model:

$$
\mathbf{Y}_{\mathrm{ijkl}}=\boldsymbol{\mu}+\mathbf{G}_{\mathrm{i}}+\mathbf{T}_{\mathbf{j}}+\mathbf{A}_{\mathrm{k}}+(\mathbf{G x T})_{\mathrm{ij}}+(\mathbf{G x A})_{\mathrm{ik}}+(\mathbf{T x A})_{\mathbf{j k}}+\mathbf{E}_{\mathrm{ijkl}}
$$

where $A_{k}$ is the effect of $k^{\text {th }}$ age; $(G x T)_{i j}$ is the interaction between genotype and calcium level; $(\mathrm{GxA})_{\mathrm{ik}}$ is the interaction between genotype and age and $(\mathrm{TxA})_{\mathrm{jk}}$ is the interaction between calcium level and age. The other factors in this model are similar to those in the first model.

Duncan's Multiple Range Test was used for evaluating the significance of the differences between group means (Duncan, 1955).

\section{RESULTS AND DISCUSSION}

Laying rate (\%) of 8 successive laying periods (28 days each) and the other parameters of egg production and body weight are presented in Tables $(3,4)$. Homozygous naked neck $(\mathrm{Na} / \mathrm{Na})$ was significantly $(\mathrm{P}<0.01)$ earlier in sexual maturity (170.9 d) than the other genotypes (173.4 d). This result is in an agreement with that reported by Abd El-Rahman (2000a,b) and Abd El-Rahman and Makled (2006).

Within genotype or calcium level the maximum laying rates were from the $2^{\text {nd }}$ to the $4^{\text {th }}$ laying periods, whereas the lowest rates were observed mainly at the $5^{\text {th }}$ and the $8^{\text {th }}$ laying periods (Table 3$)$. The results showed highly significant $(\mathrm{P}<0.01)$ effect due to genotype or calcium level with a significant interaction between the 
main factors during most of the laying periods. Under high or low temperature (Table 2) the results exhibited that naked neck genotypes $(\mathrm{Na} /-)$ had significantly more persistent effect on laying than normals especially at the last two laying periods. The average of laying periods was about $60 \%$ for the $\mathrm{Na} /-$ birds whereas it was $54.2 \%$ for the na/na genotype. Similar results were also obtained by Abd ElRahman (1990) and Abd El-Rahman and El-Hammady (2000) and Abd El-Rahman and Makled (2006).

With regard to egg number, the results showed a superiority due to the presence of $\mathrm{Na}$ gene, where egg number and laying rate during the first 3 months (E90) improved by $4 \%$ and $8.5 \%$ for the $\mathrm{Na} / \mathrm{na}$ and $\mathrm{Na} / \mathrm{Na}$ genotypes, respectively. Similar effect was observed for total egg number (TEN), where the $\mathrm{Na} / \mathrm{na}$ and $\mathrm{Na} / \mathrm{Na}$ laid more eggs than their normal partners by about $11.7 \%$ and $10.1 \%$, respectively. The presence of $\mathrm{Na}$ led to an increase in average egg weight by about $6.4 \%$ and $4.9 \%$ for the $\mathrm{Na} / \mathrm{na}$ and $\mathrm{Na} / \mathrm{Na}$ genotypes, respectively. The obtained results are in an agreement with those reported by Abd El-Rahman (2000a,b), Singh et al. (2001), ElSafty et al. (2003), Mahrous et al. (2003) and Abd El-Rahman and Makled (2006).

Table 3. Laying rate $(\%)$ of Sharkasi layers during 8 successive periods as affected by genotype (G) and dietary calcium levels (T)

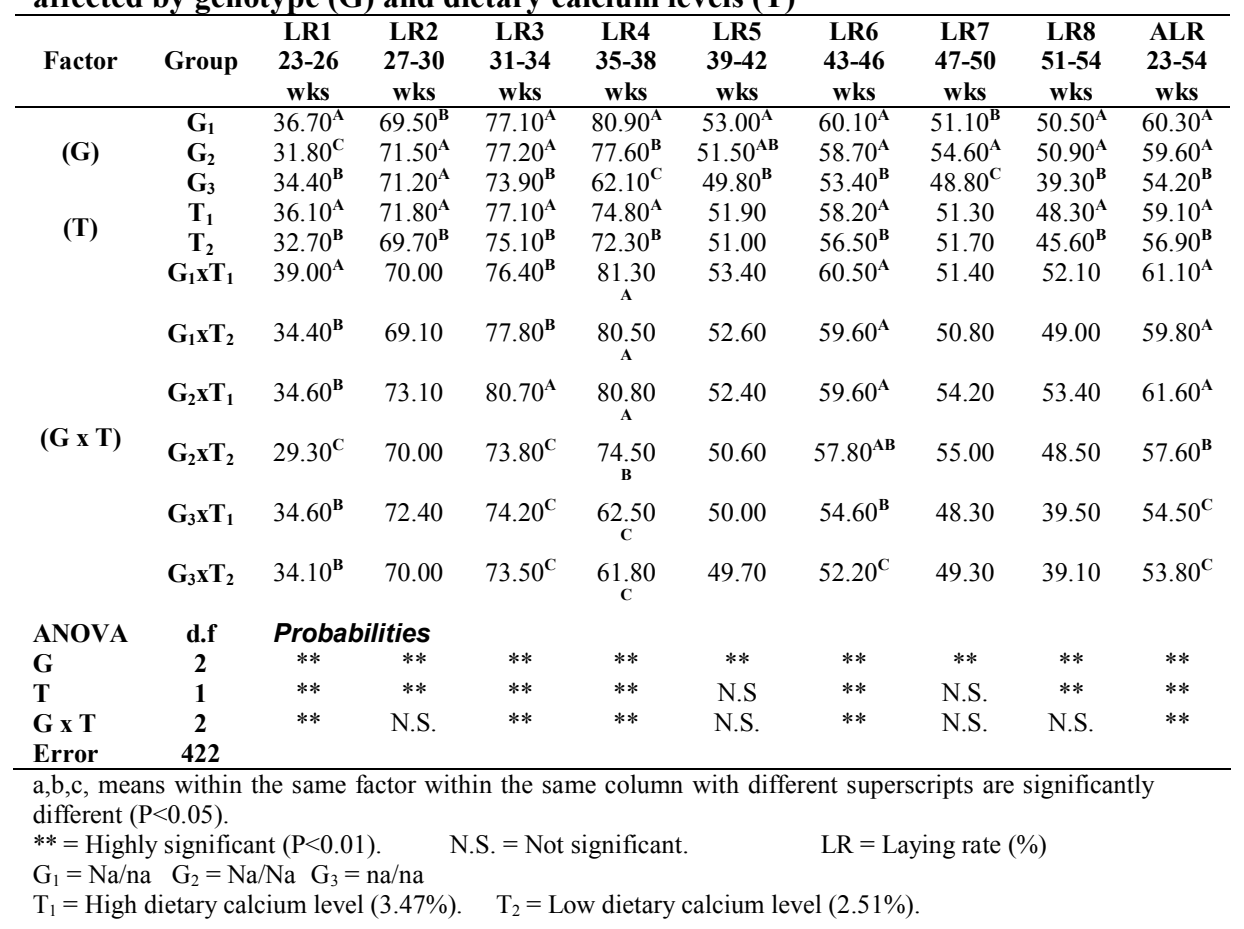


Table (4): Egg production performance and body weight of Sharkasi layers as affected by Genotype (G) and dietary calcium level (T)

\begin{tabular}{|c|c|c|c|c|c|c|c|c|c|c|}
\hline Factor & Group & A.S.M & TEN & $\begin{array}{c}\mathbf{A E W} \\
(\mathrm{g})\end{array}$ & E90 & $\begin{array}{c}\text { LR90 } \\
(\%)\end{array}$ & $\begin{array}{c}\text { TEM } \\
\text { (kg) }\end{array}$ & $\begin{array}{c}\text { W24 } \\
\text { (g) }\end{array}$ & $\begin{array}{c}\text { W40 } \\
\text { (g) }\end{array}$ & $\begin{array}{c}\text { W52 } \\
\text { (g) }\end{array}$ \\
\hline \multirow{3}{*}{ (G) } & $\mathbf{G}_{1}$ & $173.20^{\mathrm{A}}$ & $135.50^{\mathbf{A}}$ & $45.70^{\mathbf{A}}$ & $60.15^{\mathrm{B}}$ & $66.80^{\mathrm{B}}$ & $6.198^{\mathrm{A}}$ & $1323^{A}$ & 1492 & $1600^{A}$ \\
\hline & $\mathbf{G}_{2}$ & $170.90^{\mathbf{B}}$ & $133.60^{\mathbf{A}}$ & $45.07^{\mathrm{A}}$ & $62.80^{\mathbf{A}}$ & $69.80^{\mathbf{A}}$ & $6.020^{\mathrm{A}}$ & $1293^{\mathrm{B}}$ & 1471 & $1576^{\mathrm{A}}$ \\
\hline & $\mathbf{G}_{3}$ & $173.70^{\mathbf{A}}$ & $121.30^{\mathrm{B}}$ & $42.96^{\mathbf{B}}$ & $57.90^{\mathrm{C}}$ & $64.40^{\mathrm{C}}$ & $5.215^{\mathrm{B}}$ & $1288^{\text {B }}$ & 1453 & $1552^{\mathrm{B}}$ \\
\hline \multirow{2}{*}{ (T) } & $\mathbf{T}_{1}$ & $171.50^{\mathrm{B}}$ & $132.40^{\mathrm{A}}$ & $45.14^{\mathrm{A}}$ & 60.30 & 67.00 & $5.975^{\mathrm{A}}$ & 1302 & 1472 & 1580 \\
\hline & $\mathbf{T}_{2}$ & $173.70^{\mathbf{A}}$ & $127.90^{\mathbf{B}}$ & $44.10^{\mathbf{B}}$ & 60.20 & 66.80 & $5.640^{\mathrm{B}}$ & 1301 & 1473 & 1575 \\
\hline \multirow{6}{*}{$(\mathbf{G} \times \mathbf{T})$} & $\mathbf{G}_{1} \mathbf{x} \mathbf{T}_{1}$ & 171.50 & $137.00^{\mathrm{A}}$ & 46.30 & 59.59 & 66.20 & $6.340^{\mathbf{A}}$ & 1337 & 1496 & 1600 \\
\hline & $\mathbf{G}_{1} \times T_{2}$ & 174.90 & $134.10^{\mathrm{AB}}$ & 45.15 & 60.69 & 67.45 & $6.050^{\mathrm{B}}$ & 1311 & 1489 & 1601 \\
\hline & $\mathbf{G}_{2} \times T_{1}$ & 169.50 & $138.10^{\mathrm{A}}$ & 45.85 & 63.60 & 70.65 & $6.330^{\mathrm{A}}$ & 1289 & 1465 & 1580 \\
\hline & $\mathbf{G}_{2} \times T_{2}$ & 172.30 & $129.20^{\mathbf{B}}$ & 44.35 & 62.04 & 68.95 & $5.730^{\mathrm{C}}$ & 1297 & 1476 & 1570 \\
\hline & $\mathbf{G}_{3} \times T_{1}$ & 173.40 & $122.00^{\mathrm{C}}$ & 43.15 & 57.88 & 64.30 & $5.272^{\mathrm{D}}$ & 1279 & 1451 & 1555 \\
\hline & $\mathbf{G}_{3} \times T_{2}$ & 173.90 & $120.60^{\mathrm{C}}$ & 42.80 & 58.00 & 64.45 & $5.161^{\mathrm{D}}$ & 1297 & 1454 & 1550 \\
\hline ANOVA & d.f & \multicolumn{9}{|c|}{ Probabilities } \\
\hline G & 2 & $* *$ & $* *$ & $* *$ & $* *$ & $* *$ & $* *$ & $*$ & N.S. & * \\
\hline $\mathbf{T}$ & 1 & $* *$ & $* *$ & $* *$ & N.S & N.S & $* *$ & N.S. & N.S. & N.S. \\
\hline $\mathbf{G} \times \mathbf{T}$ & 2 & N.S. & $* *$ & N.S & N.S. & N.S & $* *$ & N.S. & N.S. & N.S. \\
\hline Error & 422 & & & & & & & & & \\
\hline \multicolumn{11}{|c|}{$\begin{array}{l}\text { a,b,c, means within the same factor within the same column with different superscripts are significantly } \\
\text { different }(\mathrm{P}<0.05) \text {. } \\
* *=\text { Highly significant }(\mathrm{P}<0.01) . \quad *=\text { Significant }(\mathrm{P}<0.05) \quad \text { N.S. }=\text { Not significant. }\end{array}$} \\
\hline \multicolumn{11}{|c|}{$\begin{array}{l}\text { A.S.M. = Age at sexual maturity } \mathrm{TEN}=\text { Total egg number } \mathrm{AEW}=\text { Average egg weight } \mathrm{TEM}=\text { Total } \\
\text { egg mass } \\
\text { E90 = Egg number till } 90 \text { days from sexual maturity.LR90 }(\%)=\text { Laying rate till } 90 \text { days from sexual } \\
\text { maturity. }\end{array}$} \\
\hline
\end{tabular}

As might be expected, the increase in egg number and weight due to $\mathrm{Na}$ gene improved total egg mass (TEM) of $\mathrm{Na} / \mathrm{na}$ and $\mathrm{Na} / \mathrm{Na}$, genotypes by about $18.9 \%$ and $15.5 \%$, respectively. Horst et al. (1996) found that under $18-20^{\circ} \mathrm{C}$, the $\mathrm{Na}$ gene improved egg number, weight and mass by about $13.1 \%, 3.40 \%$ and $12.9 \%$, respectively. The presence of $\mathrm{Na}$ gene improved significantly $(\mathrm{P}<0.05)$ body weight at 20 and 52 wks of age which agreed with the findings of Abd El-Rahman and Makled (2006).

Taking into consideration the effect of calcium level, the results obtained in Table (3) exhibited that high dietary calcium $(3.47 \%)$ improved significantly $(\mathrm{P}<0.01)$ the laying rate by about $4 \%$. High calcium level improved laying rate within the different laying periods whereas there were no differences due to calcium levels ( $3.47 \mathrm{vs}$ $2.51 \%)$ at LR5 and LR7. Also, high calcium level reduced significantly $(\mathrm{P}<0.01)$ age at sexual maturity by about 2.2 days (Table 4 ).

Based on these data, there was 3.5\% increase in TEN at high calcium level compared with the low calcium level. Abdallah et al. (1993) reported that egg production increased as $\mathrm{Ca}$ level increased from $2.2 \%$ to $3.9 \%$. Also, there was an increase in average egg weight by about $2.4 \%$ due to high dietary Ca level. This increase in production is consistent with the published report of Roland et al. (1996). The significant effect of high $\mathrm{Ca}$ on egg number and weight may be attributed to parallel increase in the rate of calcium absorption through the intestine and thus to its level in blood serum and in the uterine glands (El-Gendi et al., 1999). It has been reported that calcium regulates some important biological processes, including cellular information transfer, hormone biosynthesis and release (Hurwitz, 1987). 
The increase in egg number and weight due to high dietary calcium $(3.47 \%)$ improved significantly $(\mathrm{P}<0.01)$ TEM by about 6\%. Keshavarz $(1986)$ reported that egg mass was consistently lower for birds fed $1.5 \%$ or $5.5 \%$ calcium level compared to those fed $3.5 \%$. Leeson et al. (1993) reported that $2.8 \%$ calcium level was more effective for increasing egg number and weight than other calcium levels $(3.4 \%$, $3.8 \%$ and $4.2 \%$ ). Also, the results presented in Table (4) show that Ca levels $(3.47 \%$ vs $2.51 \%$ ) had no effect on body weight of birds at different ages. These results are in agreement with the findings of Chowdhury and Smith (2002).

With regard to the interaction between genotype and dietary calcium level for the important traits (ALR\% or TEN and TEM), the results in Tables 3 and 4 showed that high dietary calcium level improved the TEN and TEM but the improvement ratio was more pronounced for the $\mathrm{Na} /$ - birds than the normal feathering sibs (na/na). The improvement in average laying rate or TEN due to high calcium level was $2.2 \%$, $6.9 \%$ and $1.1 \%$ for the $\mathrm{Na} / \mathrm{na}, \mathrm{Na} / \mathrm{Na}$ and $\mathrm{na} / \mathrm{na}$ genotypes, respectively. The corresponding values of TEM were $4.8,10.5$ and $2.15 \%$ for the mentioned genotypes, respectively. In other words, the naked neck birds $(\mathrm{Na} /-)$ were more sensitive to the low dietary calcium level $(2.51 \%)$ than their normal (na/na) counterparts.

\section{Egg quality parameters}

Results of egg quality are presented in Table (5). The results exhibited no significant interactions between the main factors (genotype, calcium level, and age). The naked neck birds $(\mathrm{Na} /-)$ had heavier egg weight $(50.2 \mathrm{~g})$ than those of their normal counterparts $(48.1 \mathrm{~g})$. Eggs from the naked neck birds had higher albumen percentage with lower yolk and shell percentages. The presence of $\mathrm{Na}$ gene increased albumin $\%$ by about $3.4 \%$ and $3.80 \%$ whereas it reduced yolk $\%$ by $3.3 \%$ and $3.8 \%$ for the $\mathrm{Na} / \mathrm{na}$ and $\mathrm{Na} / \mathrm{Na}$ genotypes, respectively. The present results are in agreement with those reported by Abd El-Rahman (2000a,b, 2003) and Abd ElRahman and Makled (2006).

Table 5. Egg quality parameters of Sharkasi layers as affected by genotype (G) and calcium level (T) at different ages (A)

\begin{tabular}{|c|c|c|c|c|c|c|c|}
\hline Factor & Group & $\begin{array}{c}\text { Egg } \\
\text { weight } \\
\text { (g) }\end{array}$ & $\begin{array}{c}\text { Albumen } \\
(\%)\end{array}$ & $\begin{array}{l}\text { Yolk } \\
(\%)\end{array}$ & $\begin{array}{l}\text { Shell } \\
(\%)\end{array}$ & $\begin{array}{c}\text { Shell } \\
\text { strength } \\
\left(\mathrm{kg} / \mathrm{cm}^{2}\right)\end{array}$ & $\begin{array}{c}\text { Shell } \\
\text { thickness } \\
(\mathrm{mm})\end{array}$ \\
\hline \multirow{3}{*}{ (G) } & $\mathbf{G}_{1}$ & $51.42^{\mathrm{A}}$ & $58.10^{\mathrm{A}}$ & $31.37^{\mathbf{B}}$ & $10.54^{\mathrm{B}}$ & $4.42^{\mathrm{B}}$ & $0.381^{\mathrm{B}}$ \\
\hline & $\mathbf{G}_{2}$ & $50.03^{\mathrm{B}}$ & $58.32^{\mathrm{A}}$ & $31.26^{\mathrm{B}}$ & $10.42^{\mathrm{B}}$ & $4.18^{\mathrm{B}}$ & $0.361^{\mathrm{C}}$ \\
\hline & $\mathbf{G}_{3}$ & $48.13^{\mathrm{C}}$ & $56.20^{\text {B }}$ & $32.50^{\mathrm{A}}$ & $11.30^{\mathbf{A}}$ & $4.74^{\mathrm{A}}$ & $0.395^{\mathrm{A}}$ \\
\hline \multirow{2}{*}{ (T) } & $\mathbf{T}_{1}$ & 49.92 & 57.49 & 31.57 & $10.94^{\mathrm{A}}$ & 4.52 & $0.384^{\mathbf{A}}$ \\
\hline & $\mathbf{T}_{2}$ & 49.80 & 57.58 & 31.85 & $10.57^{\mathbf{B}}$ & 4.37 & $0.371^{\text {B }}$ \\
\hline \multirow{2}{*}{ (A) } & $\mathbf{A}_{1}$ & $48.08^{\mathrm{B}}$ & $58.13^{\mathrm{A}}$ & $31.09^{\mathrm{B}}$ & 10.78 & $4.60^{\mathbf{A}}$ & 0.382 \\
\hline & $\mathbf{A}_{2}$ & $51.63^{\mathrm{A}}$ & $56.94^{\text {B }}$ & $32.34^{\mathrm{A}}$ & 10.72 & $4.29^{\mathrm{B}}$ & 0.375 \\
\hline ANOVA & d.f. & \multicolumn{6}{|c|}{ Probabilities } \\
\hline G & 2 & $* *$ & $* *$ & $* *$ & $* *$ & $* *$ & $* *$ \\
\hline $\mathbf{T}$ & 1 & N.S. & N.S. & N.S. & $* *$ & N.S. & $* *$ \\
\hline $\mathbf{A}$ & 1 & $* *$ & $* *$ & $* *$ & N.S. & $* *$ & N.S. \\
\hline $\mathbf{G} \times \mathbf{A}$ & 2 & N.S. & N.S. & N.S. & N.S. & N.S. & N.S. \\
\hline $\mathbf{G} \times \mathbf{T}$ & 2 & N.S. & N.S. & N.S. & N.S. & N.S. & N.S. \\
\hline $\mathbf{T} \times \mathbf{A}$ & 1 & N.S. & N.S. & N.S. & N.S. & N.S. & N.S. \\
\hline Error & 230 & & & & & & \\
\hline $\begin{array}{l}\text { a,b,c, mean } \\
\text { different }(P \\
\mathrm{G}_{3}=\text { na/na }\end{array}$ & $\begin{array}{l}\text { vithin } \mathrm{tl} \\
05) \text {. * } \\
\mathrm{T}_{1}=\mathrm{H}\end{array}$ & $\begin{array}{l}\text { Highly } \\
\text { dietary }\end{array}$ & ium leve & $\%)$ & $\begin{array}{l}\text { Not sigi } \\
=\text { Low }\end{array}$ & $\begin{array}{l}\text { uperscri } \\
\mathrm{G}_{1}=\mathrm{Na} \\
\text { calcium }\end{array}$ & $\begin{array}{l}\text { significant } \\
\mathrm{J}_{2}=\mathrm{Na} / \mathrm{Na}, \\
(2.51 \%) .\end{array}$ \\
\hline
\end{tabular}


$\mathrm{Na} / \mathrm{Na}$ birds recorded the lowest shell percentage value $(10.42 \%)$ as compared with normal genotype $(11.3 \%)$. The significant reduction in shell percentage led to a significant reduction $(\mathrm{P}<0.01)$ in egg breaking strength and shell thickness. Breaking strength was $4.42,4.18$ and $4.74 \mathrm{~kg} / \mathrm{cm}^{2}$ whereas shell thickness was $0.38,0.36$ and $0.4 \mathrm{~mm}$ for $\mathrm{Na} / \mathrm{na}, \mathrm{Na} / \mathrm{Na}$ and na/na genotypes, respectively.

The remarkable disadvantage of $\mathrm{Na}$ gene in egg shell quality may be attributed to the significant increase in egg number and egg weight (Tables 4,5$)$. The reduction in egg shell quality support the findings of Abd El-Rahman (2000a,b, 2003) and Abd El-Rahman and El-Hammady (2000) who reported that reduction in shell quality was correlated with a significant decrease in serum calcium of $\mathrm{Na} /-$ birds as compared with na/na genotype. Also, Abdallah et al. (1993) reported that low egg shell hens were absorbing the calcium but had a problem of transferring it to the shell. This explanation may be another cause for reducing shell quality of $\mathrm{Na} /-$ birds. Therefore, Abd El-Rahman (2000a\&b, 2003) suggested that more studies are still needed to determine the best requirements of dietary calcium for the naked neck genotypes $(\mathrm{Na} /-)$.

High dietary calcium (3.47\%) did not affect albumen and yolk percentages, whereas it increased significantly $(\mathrm{P}<0.01)$ egg shell percentage and thickness (Table 5). The shell percentage was $10.94 \%$ and $10.57 \%$ of eggs from hens fed high $(3.47 \%)$ and low $(2.51 \%)$ dietary calcium levels, respectively. The corresponding values of shell thickness were 0.384 and $0.371 \mathrm{~mm}$, respectively.

The improvement in egg shell quality with increasing $\mathrm{Ca}$ is in an agreement with the results reported by Clunies et al. (1992), Abdallah et al. (1993), Abou-Egla (1995) and Gordan and Roland (1998). The improvement in egg shell quality due to high Ca level was presumably a result of increasing the amount of Ca consumed, $\mathrm{Ca}$ retained, and $\mathrm{Ca}$ available for egg shell deposition. Also, calcium utilization was significantly better for the high egg shell weight hens than the low egg shell weight hens as reported by Abdallah et al. (1993). Clunies et al. (1992) found that hens laying eggs with thick shells retained and utilized significantly more $\mathrm{Ca}$ than hens laying eggs with thinner shells. Clunies et al. (1992) observed that calcium levels $(2.5 \%, 3.5 \%$ and $4.5 \%)$ had no significant effect on egg production or weight, whereas shell weight increased significantly with increasing dietary calcium level. Similar result was also obtained by Gordan and Roland (1998) when birds fed on calcium levels $2.5 \%, 2.8 \%$ and $3.1 \%$. Also, it has been reported that dietary calcium levels between $2.7 \%$ and $3.5 \%$ were required to maintain optimum egg shell quality (Hurwitz and Griminger, 1960).

The results in Table $(5)$ show significant differences $(\mathrm{P}<0.01)$ due to age of birds on egg weight, albumen and yolk percentages and shell strength. Although advancing age from 40 to 52 wks reduced shell percentage and shell thickness, the differences were insignificant. It seems that reduced shell quality with aging is due to increased egg weight which in turn demands a higher shell weight without a proportional increase of the hen's ability to increase the absorption and utilization of $\mathrm{Ca}$ to fulfill a higher $\mathrm{Ca}$ demand for shell formation. Attia (1993) and Abou-Egla (1995) found that the response to dietary Ca levels on egg shell quality are dependent on age of hens. 


\section{Anatomical and physiological parameters}

Results of some anatomical and physiological parameters are presented in Table (6). The results show no significant interaction between the main factors for the most studied parameters. However, the presence of $\mathrm{Na}$ gene reduced significantly $(\mathrm{P}<0.01)$ the percentage of abdominal fat by about $32 \%$ and $47 \%$ in $\mathrm{Na} / \mathrm{na}$ and $\mathrm{Na} / \mathrm{Na}$ genotypes, respectively. The reduction may be due to the increase in egg output (egg mass) of the naked neck birds (Na/-) compared with the na/na counterparts. Similar results were obtained by Abd El-Rahman and Makled (2006). Also, the naked neck birds $(\mathrm{Na} /-)$ exhibited an significant $(\mathrm{P}<0.01)$ increase in carcass and giblets. Such increases were coincided with higher dressing percentages by about $5.60 \%$ and $5.0 \%$ of $\mathrm{Na} / \mathrm{na}$ and $\mathrm{Na} / \mathrm{Na}$ genotypes, respectively.

Table 6. Anatomical and physiological parameters of Sharkasi layers as affected by genotype (G) and dietary calcium level (T) at different ages (A)

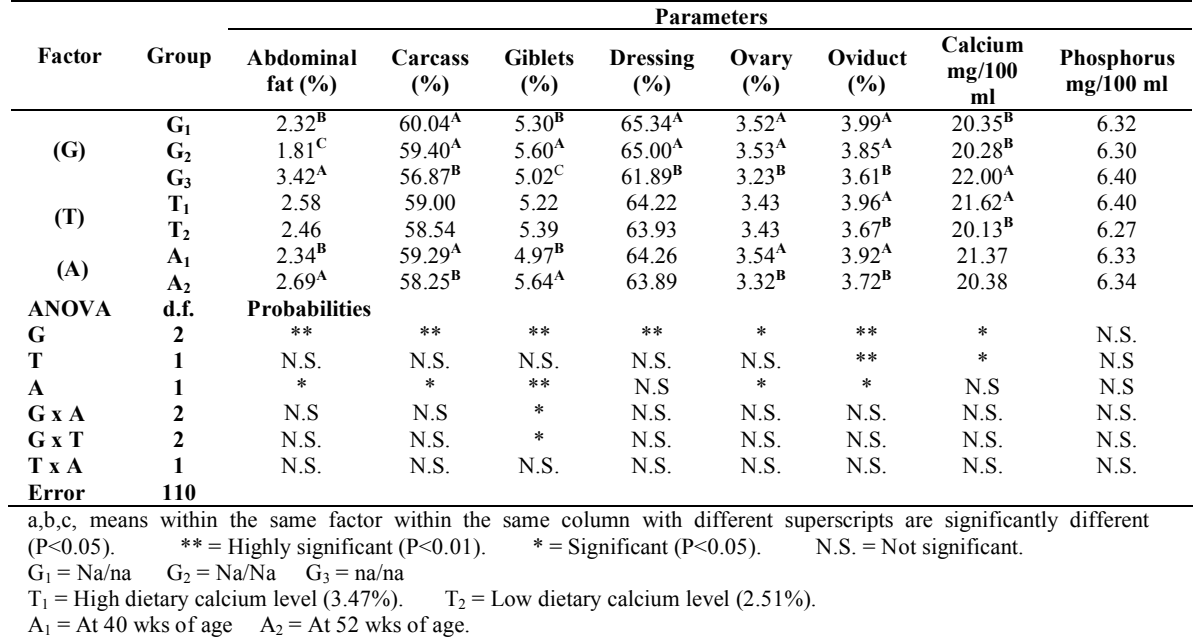

As shown in Table (6), there was an increase in ovary percentage by $8.4 \%$ and $9.3 \%$, and an increase in oviduct percentage by $10.5 \%$ and $7.0 \%$ of the $\mathrm{Na} / \mathrm{na}$, and $\mathrm{Na} / \mathrm{Na}$ genotypes as compared with na/na counterparts. Abd El-Rahman and Makled (2006) reported that the increase in the reproductive organs may due to the higher productivity of $\mathrm{Na}$ - layers than na/na or may be attributed to a linkage between $\mathrm{Na}$ gene and other genes responsible for hormone secretion.

Moreover, there was a significant reduction in serum calcium level (Table 6) due to the presence of $\mathrm{Na}$ gene. Serum calcium was $20.35,20.28$ and $22.0 \mathrm{mg} / 100 \mathrm{ml}$ for the $\mathrm{Na} / \mathrm{na}, \mathrm{Na} / \mathrm{Na}$ and na/na genotypes, respectively. The results obtained in this study confirm the findings obtained by Abd El-Rahman (2000a,b) and Abd ElRahman and El-Hammady (2000) who reported that the remarkable reduction in egg shell quality of $\mathrm{Na}$ /- birds was due to the reduction in serum calcium as a result of low absorbtion of dietary calcium. The results showed no significant differences in serum inorganic phosphorus due to genotype (Table 6).

With regard to dietary calcium level, the results indicate that calcium levels $(3.47$ vs $2.51 \%$ ) did not affect abdominal fat, carcass, giblets and dressing percentages. 
Also, calcium level had no effect on ovary percentage whereas there was a significant $(\mathrm{P}<0.01)$ increase in the oviduct by about $7.3 \%$ due to high calcium level. This increase may be due to that hens fed high calcium level $(3.47 \%)$ produced more eggs, and heavier egg weight than those fed low dietary calcium $(2.51 \%)$.

It could be stated that the level of plasma calcium increased significantly $(\mathrm{P}<0.05)$ as calcium level increased. Serum calcium was 21.62 and $20.38 \mathrm{mg} / 100 \mathrm{ml}$ from hens fed high (3.47\%) and low (2.51\%) dietary calcium levels, respectively. ElGendy et al. (1999) reported that plasma calcium was 20.5, 24.4 and $24.9 \mathrm{mg} / 100 \mathrm{ml}$ for pullets fed $3.5,4.5$ and $5.5 \%$ dietary calcium. The corresponding values for inorganic phosphorus were $7.83,7.45$ and $7.64 \mathrm{mg} / 100 \mathrm{ml}$, respectively. These results agree with the finding of Garlich et al. (1984) who reported that the serum calcium and phosphorus content of laying hens was influenced by age and production status. Also the results of Khalil and Gad (1994) indicated that hens which showed more calcium absorption produced more eggs than those of lower calcium absorption.

The results showed that no significant differences in inorganic phosphorus due to the differences in dietary calcium level. The level of plasma inorganic phosphorus may be a function of genetic action which produces enzymatic system responsible for regulating the rates of filteration or absorption. The mechanism of this regulation may be affected with the status of blood calcium homeostasis and mechanism of maintaining the electrical balance in the various body fluids compartments (El-Gendi et al., 1999). Savaliya et al. (1997) showed that alkaline phosphates enzyme is associated with calcium metabolism and egg production.

It was observed that carcass, ovary and oviduct reduced significantly with advancing age whereas the abdominal fat and giblets were increased $(\mathrm{P}<0.05)$ with advancing age (Table 6).

From the above mentioned results, it is concluded that 1) The naked neck layers (Sharkasi) exhibited a remarkable superiority for the most important productive traits. 2) High dietary calcium level (3.47\%) improved the productive performance of Sharkasi layers with an interaction between $\mathrm{Na}$ gene and dietary calcium level since the improvement due to high calcium level was more pronounced for the naked neck birds $(\mathrm{Na} /-)$ than the normal feathering (na/na) counterparts.

\section{REFERENCES}

Abdallah, A.G.; R.H. Harms and O. El-Husseiny, 1993. Performance of hens laying eggs with heavy or light shell weight when fed diets with different calcium and phosphorus levels. Poult. Sci. 72: 1881-1891.

Abd El-Rahman, A. 1990. Significance of some major genes in relation to the productive adaptability of four German sublines compared with local Egyptian chickens under Assiut subtropical conditions. Ph.D. Thesis, Assiut Univ., Assiut, Egypt.

Abd El-Rahman, A. 1998. Effect of naked neck gene (Na) on growth and carcass measurements in local Sharkasi males under Assiut conditions. Egyptian J. Anim. Prod. 35 (1998): 315-331.

Abd El-Rahman, A., 2000a. Effect of naked neck gene $(\mathrm{Na})$ and housing system on egg production performance of Sharkasi chickens under subtropical conditions. Egypt. Poult. Sci. 20: 905-926. 
Abd El-Rahman, A., 2000b. Evaluation of egg production performance of the naked neck chickens (Sharkasi) under long-term heat stress conditions. Assiut J. of Agric. Sci. 31: 269-289.

Abd El-Rahman, A., 2003. Effect of naked neck gene (Na) on egg weight loss, shell quality and hatching ability of Sharkasi chickens. Assiut J. of Agric. Sci. 34 (6): 54-69.

Abd El-Rahman, A. and H.Y. El-Hammady, 2000. Effect of frizzle (F) and naked neck $(\mathrm{Na})$ gene on productive adaptability of German genotypes as compared with local chickens under subtropical conditions. Assiut J. of Agric. Sci. 31 (2): 196-206.

Abd El-Rahman, A. and M.N. Makled, 2006. Productive performance of naked neck laying hens (Sharkasi) fed different dietary protein levels. Assiut J. of Agric. Sci. 37 (1): 85-103.

Abou Egla, E.S., 1995. Economic evaluation of reproductive traits, egg production and egg quality for dual purposes hens fed different calcium and energy levels. Egypt. Poult. Sci. 15: 383-420.

Admosun, A.A. and I.O. Kalango, 1973. Effect of calcium and phosphorus levels on the performance of layers in Nigeria. Egg production, egg shell quality, feed intake and body weight. Poult. Sci. 52: 1383-1392.

Attia, Y.A. 1993. Relationships between calcium and energy levels on egg production and quality. Ph.D. Thesis, Zagazig University.

Bar, A., V. Razaphkovsky and E. Vax, 2002. Re-evaluation of calcium and phosphorus requirements in caged laying hens. Br. Poult. Sci. 43: 261-269.

Cheng, T.K. and C.N. Coon, 1990. Effect of calcium source, particle size, limestone solubility in vitro, and calcium intake level on layer bone status and performance. Poult. Sci. 69: 2214-2219.

Chowdhury, S.R. and T.K. Smith, 2002. Dietary interaction of 1,4-Diaminobutane (Putrescine) and calcium on egg shell quality and performance in laying hens. Poult. Sci. 81: 84-91.

Clunies, M.; D. Parks and S. Leeson, 1992. Calcium and phosphorus metabolism and egg shell formation of hens fed different amounts of calcium. Poult. Sci. 71: 482489.

Duncan, D.B., 1955. Multiple Range and F-tests. Biometrics, 11: 1-42.

El-Gendi,. G.M., A.A. Radwan and M.Z. Nofal, 1999. A trial to improve layer performance and calcium absorption rate as affected by dietary calcium and vitamin D3 levels. Egypt. Poult. Sci. 19: 761-777.

El-Safty, S.A.; M.M. Fathi; A.H. El-Attar and A.Z. El-Dein, 2003. Laying performance of naked neck and normally feathered genotypes of chicken produced from different parental lines. Egypt. Poult. Sci. 23 (1): 169-181.

Galal, A. and M.M. Fathi, 2002. Introducing crest gene to enhance productive performance of naked neck chickens under moderate ambient temperatures. Egypt. Poult. Sci. 22: 611-628.

Garlich, J., J. Brake, C.R. Parkiurst, J.P. Tilaxton and G.W. Morgan, 1984. Physiological profile of caged layers during one production year. Molt and postmolt, egg production, egg shell quality and blood parameter. Poult. Sci. 63: 339-343. 
Gilbert, A.B.; J. Peddie; G.G. Mitchell and P.W. Teague, 1981. The egg laying response of the domestic hen to variation in dietary calcium. Br. Poult. Sci. 22: 537-548.

Gilbert, A.B.; M.M. Perry; D. Waddington and M.A. Hardie, 1983. Role of atresia in establishing the follicular hierachy in the ovary of the domestic hens. J. of Reprod. and Fertility 69: 221-227.

Gordon, R.W. and D.A. Roland, Sr. 1998. Influence of supplemental phytase on calcium and phosphorus utilization in laying hens. Poult. Sci. 77: 290-294.

Horst, P. and P.K. Mathur, 1994. Feathering and adaptation to tropical climates. In "Proceeding of $9^{\text {th }}$ European Poultry Conference. Glasgow U.K. 7-12 August, pp. 79-82.

Horst, P.; P.K. Mathur and A. Valle. Zarate, 1996. Breeding policies for specific tropical environments using appropriate combination of major genes. In "Proceeding of XX World's Poultry Congress", New-Delhi, India 2-5 September, 1996, pp. 633-640.

Hurwitz, S., 1987. Effect of nutrition on egg quality. Pages 235-254. In Egg Quality-Current Problems and Recent Advances. R.G. Wells and C.G. Belyavin ed. Butterworths, London U.K.

Hurwitz, S. and P. Griminger, 1960. Observation on the calcium balance of laying hens. J. Agric. Sci. 54: 373-377.

Keshavarz, K., 1986. The effect of variation of calcium intake on production performance and shell quality. Poult. Sci. 65: 2120-2125.

Khalil, H.M. and H.A.M. Gad, 1994. Calcium absorption rate relative to histological intestinal villi characteristics and egg production of turkey hens. Egypt. Poult. Sci. 14: 161-190.

Leeson, S.; J.D. Summers and L. Caston, 1993. Response of brown-egg strain layers to dietary calcium or phosphorus. Poult. Sci. 72: 1510-1514.

Mahrous, M.A.; A. Galal; M.M. Fathi and A. Zein El-Dein, 2003. Improving productivity of layer chickens in hot environmental conditions by introducing naked neck and frizzle genes. Egypt. Poult. Sci. 23: 393-408.

Merat, P., 1990. Pleiotropic and associated effects of major genes. p. 429-467. In Poultry Breeding and Genetics. R.D. Crawford Elsevier Scientific Publishers, Amsterdam, Netherlands.

National Research Council, 1994. Nutrient requirements of Poultry. $9^{\text {th }}$ ed. National Academy Press. Washington, DC.

Roland, D.A.Sr., M.M. Bryant and H.W. Robon, 1996. Influence of calcium and environmental temperature on performance of first cycle (Phase 1) commercial Leghorns. Poult. Sci. 75: 62-68.

SAS User's Guide: Statistics, 1990. SAS Institute, Inc. Cary, NC., U.S.A.

Savaliya, F.P., R.K. Shukla, K. Khanna and B.P. Brahmkshtri, 1997. Inheritance of serum alkaline phosphatase level and certain economic traits in pure and reciprocal cross of White leghorn strains. Indian J. Anim. Sci. 67: 156.

Singh, C.V., D. Kumar and Y.P. Singh, 2001. Potential usefulness of plumage reducing naked neck $(\mathrm{Na})$ gene in poultry production at normal and high ambient temperatures. World's Poult. Sci. 57: 139-156.

Sohail, S.S. and D.A. Roland, Sr., 2002. Influence of dietary phosphorus on performance of Hy-Line W36 hens. Poult. Sci. 81: 75-83. 


\section{تأثير مستويات الكالسيوم على الأداء الإنتاجى للاجاج العارى الرقبة (الثركسى)}

\section{محمد نبيل مقلد ، أسعد عبد الرحمن}

\section{قسم الإنتاج الحيواتسى والدواجن، كلية الزراعة، جامعة أسيوط، أسيوط}

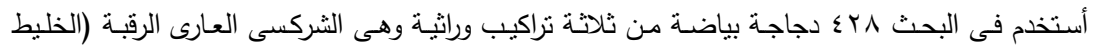

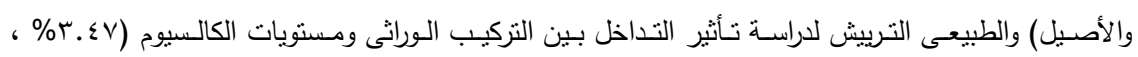

$$
\begin{aligned}
& \text { 1. }
\end{aligned}
$$

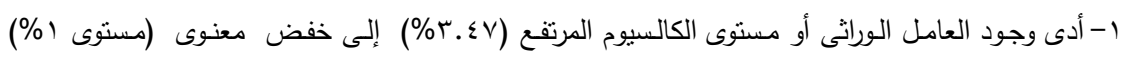

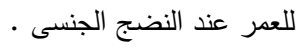

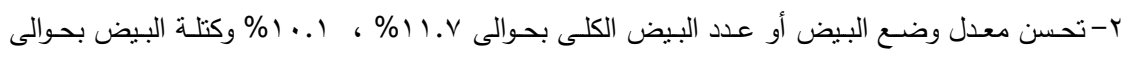

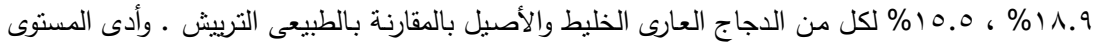

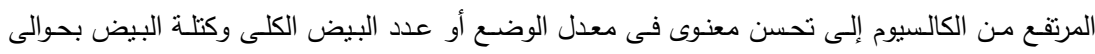

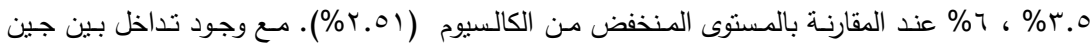

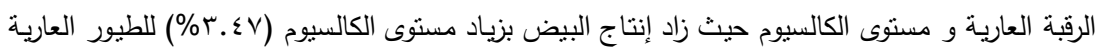

$$
\begin{aligned}
& \text { الرقبة بالمقارنة بالطيور الطبيعية الترييش. }
\end{aligned}
$$

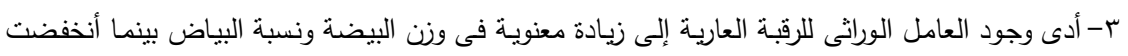

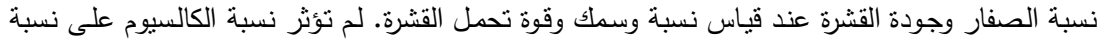

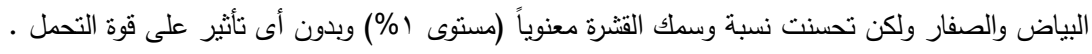

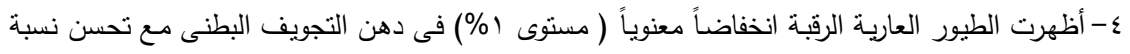

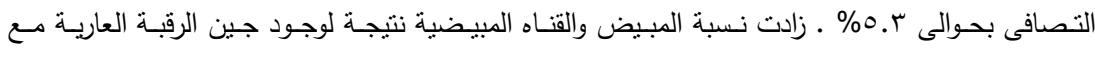

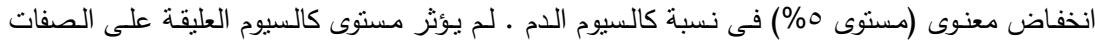

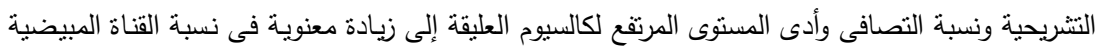

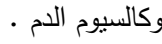

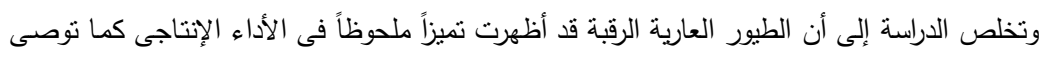

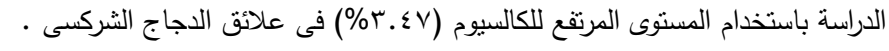

